\title{
Et tilbageblik
}

\author{
af Helle Gotved
}

\section{Undren og beundren}

Åh, min lykkelige barndom i Gymnastikhuset. Lydene fra salen vækkede mig om morgenen: kraftfyldte kommandoer og taktfast march mens mændene sang: „Høje nord - sangens bo«. Om formiddagen var det damernes tur. Time efter time kunne jeg sidde musestille på balkonen og betragte det underfulde, der skete. Med læggede skørtebukser og højhalsede sweatere, lange strømper og snøregymnastiksko stod de der på fire rækker og gjorde »hofter fat og knæ dybt bøj«. Lærerinden havde skinkeærmer og tornure, valk $\mathrm{i}$ håret $\mathrm{og}$ lorgnetter. Hun kommanderede, så det var en lyst, og de fire rækker adlød med appel. Sommetider blev der kommanderet: »Hvil«, og så tog. de hænderne på ryggen og strakte den ene fod frem. Ellers vendte fødderne skråt ud til siderne. I slutningen af timen slæbte de hest og buk frem, tog tilløb og øvede bedrifter, og så marcherede de rundt og sang: »De gamla, de kloka må le, le, le«.

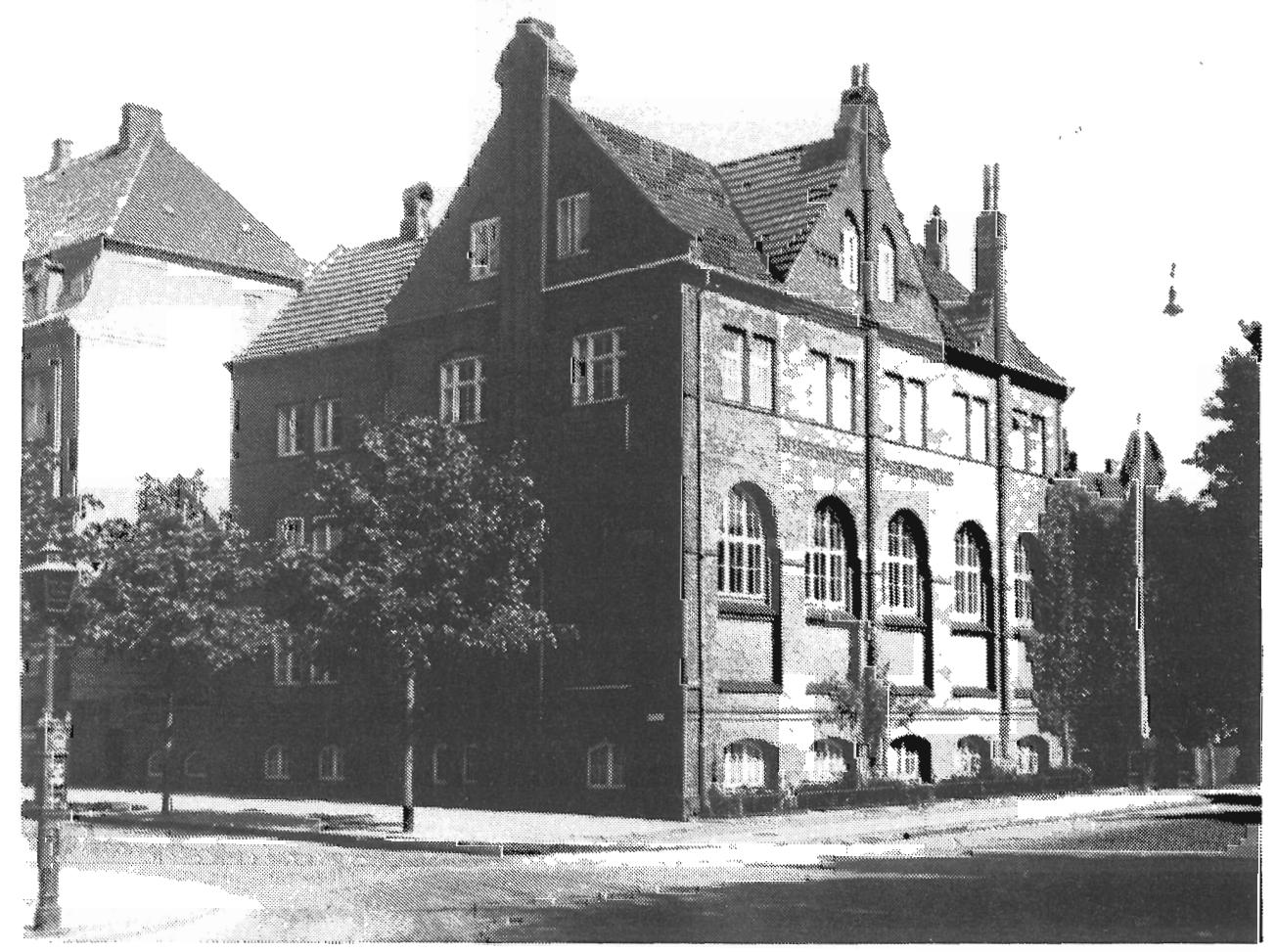


Det var forunderligt at se på, og der var ikke tvivl i min sjæl om, at lærerindens plads engang skulle være min.

Om søndagen ejede jeg salen, og alt hvad der havde været af nyt i ugens løb blev prøvet. På den måde er jeg helt naturligt kommet til at følge kvindegymnastikkens udvikling gennem årene på nærmeste hold, og når jeg nu ser tilbage, husker jeg meget tydeligt de forskellige skift imellem systemerne.

\section{Grundlaget}

Men først lidt om grundlaget for det hele. Far døde, da jeg var lille, og derfor har mor fortalt så meget om hans livsindstilling og gerning, at jeg kunne forstå hvad Gymnastikhuset var bygget til.

I 1880 var far som polytekniker knyttet til Vallekilde Højskole som lærer - bl.a. i gymnastik. Ved en nordisk gymnastikfest i Stockholm så han den Lingske gymnastik og blev begejstret.

Om P. H. Ling er der skrevet:

»Til kampesalens lekar han landets ungdom drog, han ville fostre ekar uti den unge skog, han ville styrkan lifva hos oss på nyt igen, han ville norden gifva tilbaka sina män«.

Det er forståeligt, at en der kom fra den tids folkehøjskole kunne blive fanget af disse tanker, for det faldt helt i tråd med, hvad der blev forkyndt fra højskolens talerstol - om mennesket skabt i Guds billede.

Far følte sig stærkt draget mod denne nye gymnastik. Afbrød sin polytekniske karriere og tog til Stockholm for at få den fulde uddannelse på Centralinstituttet, hvor eksamen gav ham titlen Gymnastikdirektør. »Nu vil jeg ikke længere bygge huse - men mennesker «, sagde far.

Far indførte den Lingske gymnastik på Vallekilde Højskole i 1884, og den fængede hurtigt ude i landet, hvor tiden var moden til den. Et par år efter blev far af Ernst Trier (forstander på Vallekilde) opfordret til at prøve at vinde hovedstaden for denne nye form for gymnastik, og i 1887 stiftedes så »N.H. Rasmussens gymnastiske institut «. Undervisningen foregik i forskellige skolesale. Først elleve år senere var fars $\emptyset$ konomiske situation sådan, at han kunne bede sin ven, arkitekt P.V. Jensen Klint, om at tegne Gymnastikhuset. Det stod færdigt i 1898.

Det var ikke elitegymnastik, der interesserede far - tværtimod. Mor har fortalt, at en tilskyndelse til at vælge denne livsgerning var en uforglemmelig oplevelse, far havde på sin konfirmationsdag. Konfirmanderne skulle en efter en stå frem på kirkegulvet og fremsige et vers, og da turen kom til en lille forvokset og pukkelrygget dreng, sagde han højt og klart: »Så er vi alle kongebørn - skønt fattige og ringe«.

\section{Systemer}

Det første system, jeg oplevede, blev således P. H. Lings svenske gymnastik. En rationel formgivende mandsgymnastik som byggede på en skematisk opdeling af krop- 
pen efter anatomiske grundprincipper og med øvelser for de forskellige afsnit. Altså nærmest et sygegymnastisk princip brugt på sunde.

Ethvert system indeholder byggesten, og Ling lagde vel grundstenen! Selv om vi nu - 100 år efter den Lingske gymnastiks indførelse i Danmark - mest dyrker helhedsbevægelse, kommer vi aldrig fra at skulle beskæftige os med delen også.

Forud for et system går altid erkendelsen af et behov, og når kvinderne med så stor begejstring deltog i mandsgymnastik, var deres behov simpelthen frigørelse. De fik endelig lov til at være med i salen og gøre de samme ting, som mændene gjorde - og de nød deres frihed. Jeg husker deres strålende ansigter og deres energi, når de udførte de maskuline øvelser.

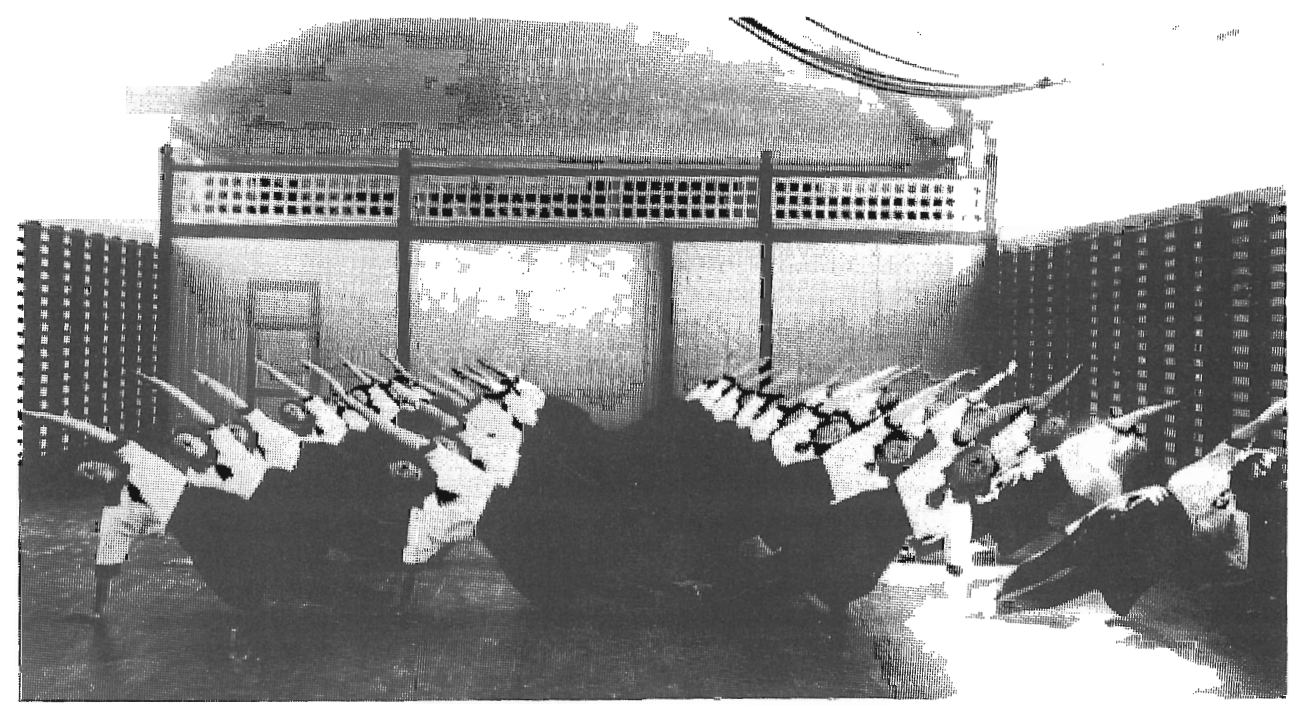

Årene går, og gymnastikken skifter gradvis karakter. Da kvinderne længe nok havde prøvet at være mænd, ville de gerne være kvindelige igen. Der opstod en trang til løsrivelse fra mandsgymnastikken og til at få en gymnastik som passede bedre til kvindens organisme og psyke.

Elli Björkstens navn vil altid lyse, fordi hun evnede at tilfredsstille dette behov, og især fordi hun igennem sin personlige udstråling kunne begejstre andre. Fagligt samlede hun faktisk norden på årligt tilbagevendende sommerkurser, hvor deltagerne både fik øvelsesstof og inspiration.

Elli Björksten var finne - en renhjertet idealist og en fremragende pædagog. Hendes valgsprog var:

»Livets sköna kunst är: leva själv och liva, värme taga mot - och värme giva«.

Barnet på balkonen oplevede systemskiftet ved, at der gradvist kom nye øvelser. Det var ikke længere udelukkende det firkantede bøj-stræk, nu kom der også bløde sving og fantasifulde øvelser. Gymnastikdragten blev ændret til kitler, og damerne havde 
bare ben og arme. Lærerinden kommanderede ikke længere, hun underviste inspireret - der kom en anden lyd på!

Hver gang gymnastikken ændrer stil, bliver lyden ændret med den. I Björkstengymnastikken blev der lagt uhyre vægt på stemmeføringen (det hed ikke længere kommando - men tilsigelse), og den, der bare én gang har hørt Elli Björkstens stemme, når hun underviste, glemmer det næppe.

Lyd er suggererende, og Elli Björksten overførte sin glæde og vilje og sine syner til eleverne. Hun ville frigøre dem, og det lykkedes for en stor del af psykiske grunde, og det var bl.a. deri hendes styrke bestod. Svagheden var derimod den vaklende teori, der begrundede - eller rettere ikke begrundede selv $\varnothing$ velsesstoffet.

Elli Björksten var stor nok til at indse, at hendes $\emptyset$ velsesstof ikke var fuldendt, og hun ønskede, at hendes elever skulle bygge videre og udvikle systemet. Derfor har dette system fået så relativ lang levetid.

Personligt har jeg oplevet Björkstengymnastikken stærkest og renest på Snoghøj Gymnastikhøjskole, hvor to af Elli Björkstens begavede elever og arvtagere, Jørgine Abildgård og Anna Krogh, holdt gymnastikkens fane højt. De spredte kendskabet til denne nordiske gymnastik ud over hele landet ved hjælp af deres dertil uddannede og opildnede delingsførere. Måske kender de fleste Björkstengymnastikken bedst under navnet: Snoghøjgymnastik.

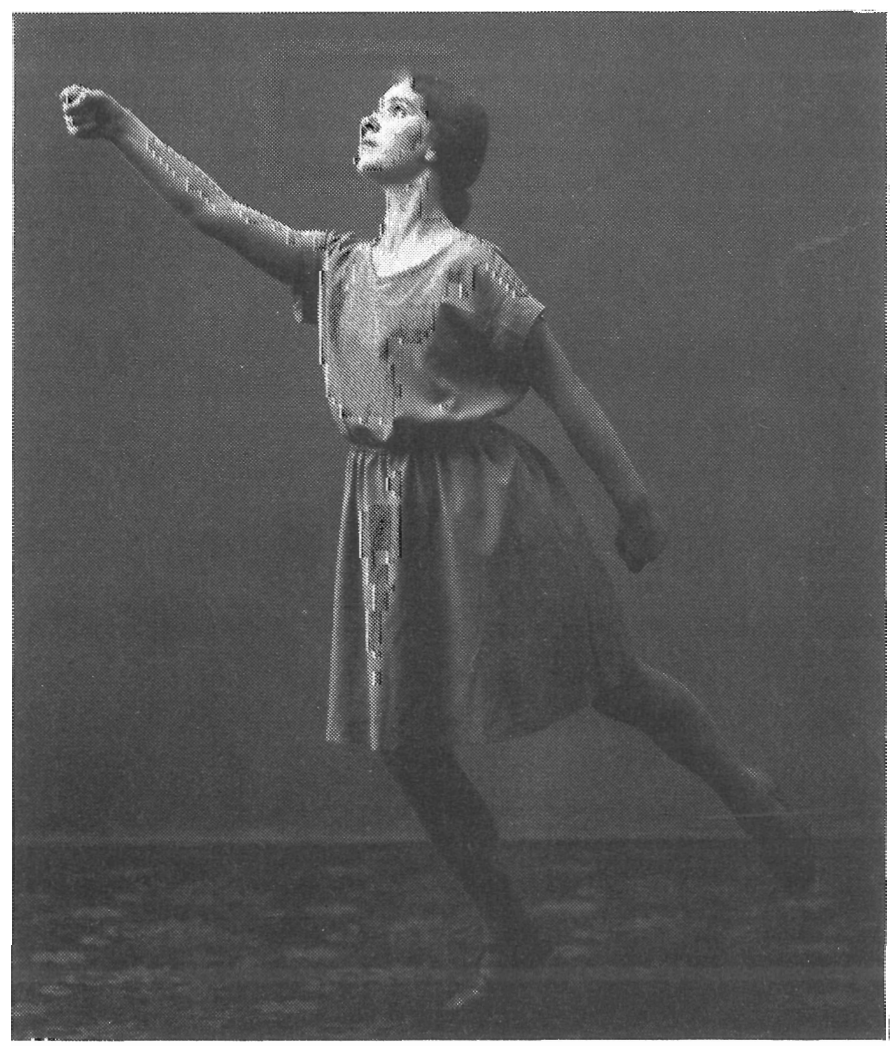


På samme tid blev der fra Gymnastikhøjskolen i Ollerup sendt ligeså mange begejstrede unge ud, der var opdraget med Niels Buhks gymnastik.

Niels Bukh var mandsgymnastikkens fornyer. Han ændrede den fra stillingsgymnastik til en bevægelsesgymnastik, der i et voldsomt tempo gav ekstrem smidighed. Der var også kvindelige elever i Ollerup, og der var heftige og til tider fanatiske diskussioner for og imod disse to vidt forskellige systemer: Ollerup kontra Snoghøj. Først mange år efter er det gået op for mig, at den grundlæggende forskel bestod i, at det ene system sigtede mest på kroppen - det andet på sjælsindholdet.



Niels Bukh har ganske vist været med til at præge kvindegymnastikken i en årrække, men jeg mener nu ikke, at den form for gymnastik har betydet væsentligt for udviklingen af kvindens bevægelseskultur. Hans opvisninger var flotte, og hans gymnastik blev verdenskendt. Videnskabeligt er der sat et stort spørgsmålstegn ved hensigtsmæssigheden i Bukhgymnastikken, men det var et fascinerende syn at se de snorlige rækker og den præcise udførelse. Lydene var korte og knappe tilråb - ingen pauser mellem øvelserne - der var tempo og effektivitet.

I disse år holdt klaveret sit indtog i gymnastiksalen.

Næsten samtidig med Elli Björksten skabte også Agnete Bertram en form for kvindegymnastik. (Jeg tror, at Elli Björksten første gang havde en offentlig opvisning med musik i 1912 - Agnete Bertram i 1918).

Hvor Elli Björkstens $\emptyset$ velser var sammensatte og motivistisk opbyggede, lagde Agnete Bertram vægten på de ganske enkle bevægelser, kædede dem sammen i serier til klassisk musik og kaldte systemet »naturlig gymnastik «. Hun byggede på professor Lindhards teorier, og hendes smag var sikker. I modsætning til Elli Björksten krævede 


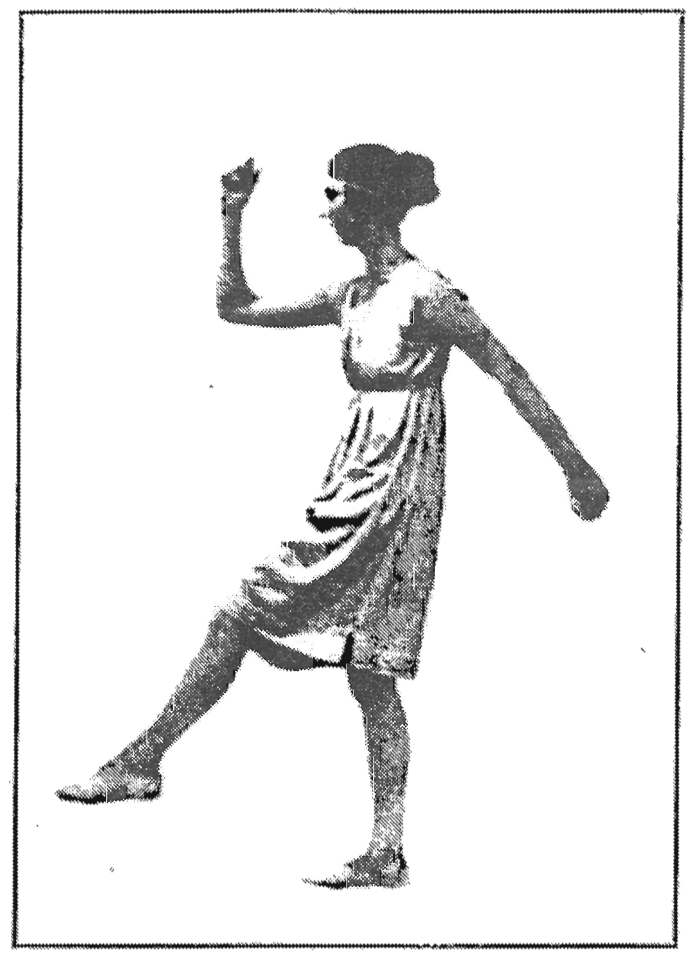

Agnete Bertram af sine uddannede lærerinder, at de intet måtte ændre. Forståeligt nok, for hendes $\emptyset$ velsesserier var fuldendt arbejde, men det dømte systemet til at blive en indkapslet epoke.

Agnete Bertram havde studentergymnastikken ved universitetet i København, så hendes system fik på den måde indpas i gymnasier.

Ling - Björksten - Bukh - Bertram - fire vidt forskellige systemer.

\section{Visioner}

Som nævnt havde det altid været en selvfølge for mig, at jeg skulle overtage lærerindens plads i Gymnastikhusets sal, men egentlig begejstret for gymnastikken blev jeg først, da jeg kom på højskole. Her delte jeg værelse med Niels Bukhs søsterdatter og fik gymnastikinteresserede kammerater samt en overordentlig-dygtiggymnastiklærerinde, Asta la Cour Pedersen, der underviste livfuldt i Björkstengymnastik.

Nu fik jeg også lejlighed til at se elitegymnastik og opvisninger. Hjemme i Gymnastikhuset var det jo udelukkende motionsgymnastik for almindelige mennesker i alle aldre (langt fra skønhedsidealer), men nu fik jeg udvalgte gymnaster at se. Horisonten blev udvidet. 
Især husker jeg landsstævnet på Dybbøl i 1928 - og fra det ganske specielt et hold kvinder fra Finland. De bevægede sig med en betagende skønhed, og jeg glemmer aldrig synet - nok fordi det var et stærkt førsteindtryk. Der blev født en drøm.

Alt ialt store ungdomsoplevelser der gav lyst til personlig dygtiggørelse. Det fik jeg rig lejlighed til hjemme, hvor der var en lærerinde, der underviste festligt i Björkstengymnastik, og hende gik jeg hos elleve timer om ugen og blev virkelig dygtig - til det system! Man skulle holde regnskab med en masse variationer, og man skulle anspænde sig og holde ud (med smil på læben). Det var helt i overensstemmelse med min opdragelse. Endvidere var der redskabsøvelser, som jeg elskede, for her skulle udvises mod og behændighed.

Alt imens glædede jeg mig til at blive uddannet til gymnastiklærerinde. Min plan var omfattende: Først seminarium, dernæst G.C.I. i Stockholm, til slut et år hos Elli Björksten i Helsingfors. Så ville jeg overtage Gymnastikhuset hjemme.

Sådan skulle det ikke gå, for jeg forlovede mig med en gymnastiklærer, der var så meget ældre end jeg, at det ville være urealistisk at begynde på en så lang uddannelse. Derfor måtte jeg nøjes med Statens eetårige uddannelse i første omgang og så supplere med kurser senere hen.

\section{Skuffelse}

Det ene år så jeg frem til med meget store forventninger, men gymnastikken blev desværre en stor skuffelse for mig. Jeg havde glædet mig til at få Nanna Reimer, som jeg havde hørt så meget om, men netop dette år ville professor Lindhard indføre Bertramgymnastik på instituttet, fordi dette system var bygget på hans teorier.

Her var ingen sang - ingen begejstring - ingen opildnende tilråb. Her vắr høflige henstillinger og venlig samtale. Vi skulle være yndefulde, men ingen kunne forklare, hvordan man blev det. Vi rørte ikke redskaberne en eneste gang hele det år - der var ingen brug for mod og dristighed. Overgangen fra at være den dygtigste på et hold til at være en fiasko $i$ et andet system var svær at tage.

Min lærerinde var uden skyld - dengang kendte man ikke til undervisning i afspænding (ophør af overflødig spænding) som grundlag for koordinering. Hun kunne kun foreskrive de yndefulde attituder og henvise os til at gøre øvelserne på samme måde, som den velkoordinerende elev gjorde det. Hun var yndig, lige meget hvad hun lavede. Jeg har set den samme optræde som henholdsvis Bukh-, Björksten-, Bertram- og senere hen Medau-gymnast, og hver gang var det bare som en ny klædelig dragt hun tog på.

Vi var flere, der sørgede over at være håbløst klodsede og urytmiske, og vi var gladest, når gymnastiktimerne var forbi. Livet har siden lært mig, at ingen er urytmisk, men man kan være så anspændt, at opfattelsen af rytme bliver umuliggjort.

Det var ikke alene gymnastikken, der skuffede mig. Jeg havde også glædet mig til at lære om anatomi, for jeg troede, det havde noget med bevægelse at gøre. Men det viste sig at handle mest om et brunt skelet i et skab - om latinske navne og huskestof. Der var ikke noget om funktionel bevægelse. 
I timerne med gymnastikteori savnede jeg tit sammenhæng imellem det, vi lærte i teorilokalet, og det, der foregik i salen. F.eks. lærte vi »gangen er et fortsat fald «, men som vi gik, måtte det blive bagud! Lyden var det også galt med. Vi lærte hvad vi skulle sige, og hvornår vi skulle sige det - men ikke hvordan.

Musikteorien bestod i at tælle takter og perioder og beregne $\emptyset$ velser i serier til musikken. Men vi lærte ikke at lytte.

Jeg ved, at jeg er hård i min kritik. Det skyldes, at forventningerne var så enorme. For selvfølgelig var det da et godt år på mange måder, og der var også timer, jeg var udelt glad for. Gymnastikkens historie f.eks. Da hørte vi bl.a. om GutsMuths som i 1770 skrev i: »Gymnastik für die Jugend « - »Und so sei denn der einzige Hauptzweck der Gymnastik Harmonie zwischen Leib und Geist «! Og som i Schneptenthal netop inddelte sit øvelsesstof efter funktioner og ikke som nu på instituttet her rationelt efter kropsdele!

Leg og boldspil var jeg meget glad for, men for mig, som udelukkende skulle undervise i motionsgymnastik for voksne, var det ganske naturligt selve gymnastikken, der var hovedsagen. Derfor den store skuffelse.

\section{Eksperimenterne}

I juni 1932 stod jeg med eksamensbeviset, og samtidig overtog min mand - tegner og gymnastiklærer Aage Gotved - og jeg Gymnastikhuset. Mor havde ledet det siden fars $\mathrm{d} \varnothing \mathrm{d}$.

$\mathrm{Nu}$ - endelig! Mine drømme skal realiseres. Nu skal der undervises som aldrig før. Blandt andet skal jeg overtage nogle hold fra en ældre lærerinde, som advarer eleverne mod deres nye lærerinde, fordi hun slet ingen erfaring har. Det fortørner mig, for hvad skal man med erfaringer - det er vel ikke det, der er det afgørende for undervisningens kvalitet. Det vigtigste er vel, at man har idealer - og mod og lyst til at gå igang med opgaverne!

Jeg ved nøje, hvordan undervisningen skal være. Først og fremmest skal den være festlig. Den skal være effektiv. Timerne skal indeholde alle de bedste $\varnothing v e l s e r, j e g$ kan finde, og musikken skal passe helt perfekt. Fire systemer ejer jeg, så jeg kan bare vælge det bedste fra hver af dem. Der skal være ny timeseddel hver måned, så eleverne kan blive $\emptyset$ mme nye steder. Ømheden er nemlig bevis på, at de har trængt til øvelsen. Tror jeg!

Det gik storartet nogle år.

Hvis nogen elever meldte fra og angav som grund, at de ikke kunne tåle gymnastikken, syntes jeg, det var kedeligt for dem. At der skulle være noget i vejen med min aldeles udmærkede gymnastik, strejfede ikke min tanke.

Hveranden undervisningstime er der pianistinde, og besparelsen forklares med, at man bedre kan fordybe sig i at lære øvelserne den dag, der ikke er musik. Musikledsagelse kan godt være problematisk. 
Musik til gymnastik blev dengang stort set brugt efter to metoder:

1. Enten blev der fundet velegnet musik, og øvelserne blev udformet, så de passede til musikken.

2. Eller der blev lavet øvelser først, og så ledte man efter musik, der kunne bruges til.

Dansen adskiller sig fra gymnastikken i det, at den har sin egen musik. Vi vil aldrig sige: spil noget, der passer til en vals, men i gymnastikundervisningen siger vi: spil noget, der kan bruges til løb.

Musikken og gymnastikken er to forskellige elementer, som skal passes sammen. Det er svært. De fleste gymnastiklærerinder fra den tid kender til at sidde sene nattetimer og lede i noderne. Til sidst nøjes man med et kompromis og tager noget, »der kan bruges«. Evt. overlader man valget til pianistinden. Scubert og skøjteløbervalsen i en pèle mèle.

Det er også utilfredsstillende i længden at blande systemer. Systemskaberen mente jo at have fundet det ideelle - men hvem har ret? Hvad er det, jeg leder efter?

Hvert forår var der store opvisninger i Idrætshuset af eliteholdene fra alle de forskellige gymnastikforeninger, og de blev naturligvis fulgt med stor interesse - og med kritik. Efterhånden kom jeg til den erkendelse, at gymnastisk dygtighed ikke behøver at være ensbetydende med skønhed. Hvad er der i vejen med gymnastikken? Deltagerne er så dygtige, at de ikke kan blive dygtigere. Næsen ligger presset ned imellem anklerne i foroverbøjet stilling, og vridningerne bliver ført til absolut yderste grænse. Een tand til og de går i stykker. Det ser bare ikke godt ud. Det er en uskøn dygtighed. Man bliver ikke glad af at se på det. Det må være noget galt. Her er perfektion - ikke liv. Der mangler noget.

Men det kom.

\section{Medau}

1936 blev et skelsættende år. Både for kvindegymnastikkens udvikling - og for mig. Nu kom det femte system. Hinrich Medau, som byggede på Rudolf Bodes principper, gav opvisning i Idrætshuset. Dette var fundamentalt anderledes, end hvad vi før havde set. Det var totalbevægelse. (Rudolf Bode har i 1910 defineret totalbevægelse: en rytmisk strømmende bevægelse der omfatter helheden). Her var liv og her var skønhed. Her var bevægelseskultur og kunst.

Salen kogte af begejstring.

I alle hidtil kendte systemer var øvelserne rettet mod et mål, men her var bevægelsen målet i sig selv. Medau sad ved flygelet og skabte et dynamisk lydbillede af, hvad man folte i bevægelsen - ikke en reproduktion af hvad man så. Det var selve impulsen og forløbet, der på fremragende vis blev levendegjort i musikken - melodisk spænding og afspænding, fjedren og svingen. Det var ikke musik til bevægelse, det var bevægelsesmusik, og det var så hjertegribende skønt, at jeg græd. For dette ville jeg aldrig kunne få del i.

I dagene efter opvisningen holdt Medau et kursus i Studenterforeningen, og der sad jeg med ørene vidt åbne og noterede rytmer og prøvede at huske det hele. Det gjorde 
stort indtryk på mig, at da Medau et øjeblik forlod lokalet og vinkede en af eleverne (Senta Medau) op, for at hun kunne afløse ham, satte hun sig ved flygelet og underviste og spillede på samme måde som han. Det virkede mirakuløst. Det kunne ikke være et tilfælde. To genier kunne ikke have mødt hinanden - den ene måtte have lært det. I dette $\varnothing$ jeblik traf jeg en beslutning: Dette ville jeg lære.

Det var alvor. Her var det, jeg ubevidst havde søgt: den fuldkomne harmoniske bevægelse helt i overensstemmelse med musikken.

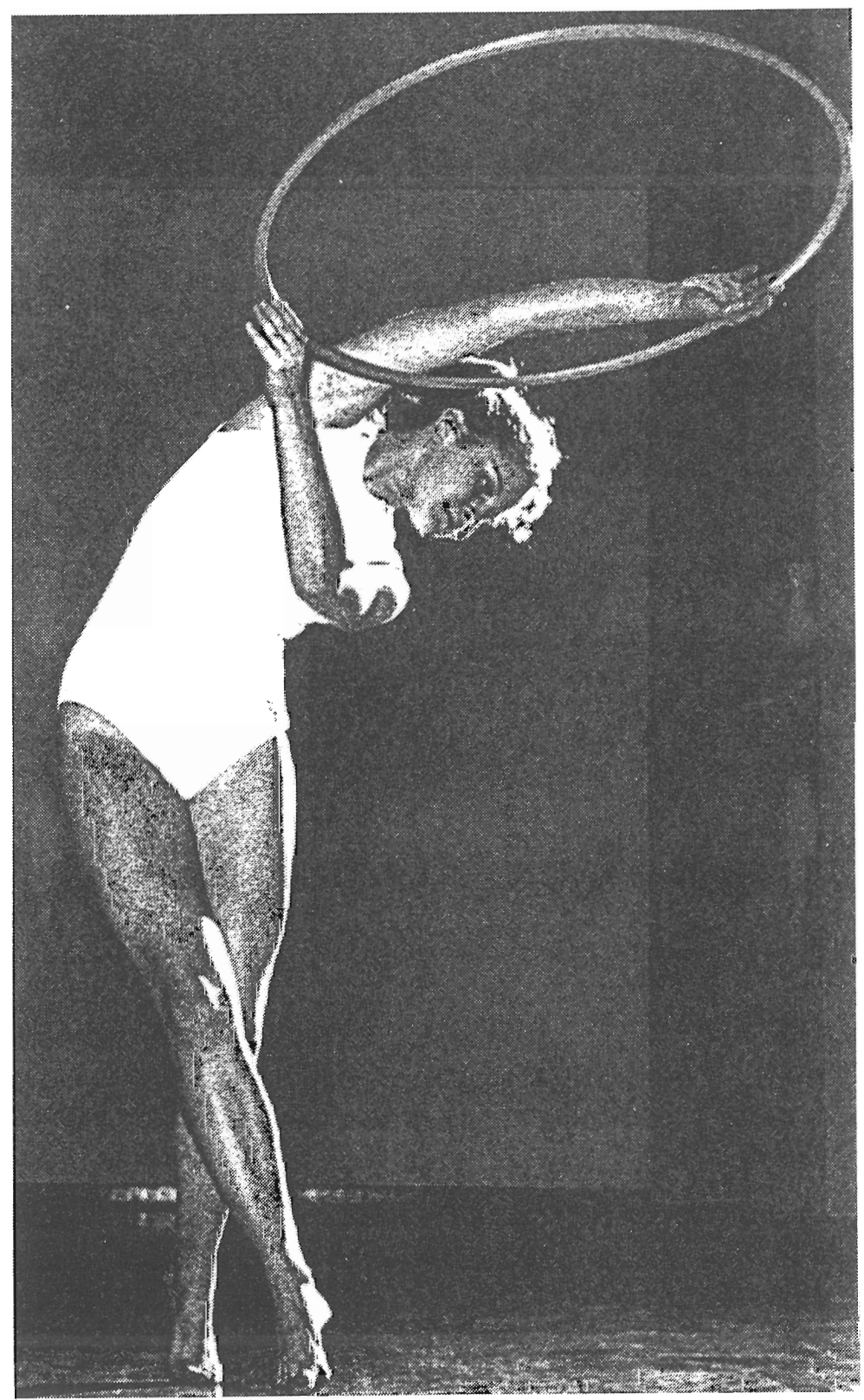


Foreløbig blev der sat et nyt krydderi på den sammenkogte ret, som min gymnastik var: totalbevægelse med køllesving. De sidste ti minutter i hver time blev brugt til at fors $\emptyset$ ge dette nye. Det måtte blive efter »laissez faire «-metoden. Samtidig begyndte jeg at tage undervisning i komposition og søgte ind i konservatoriets underskole.

Den, der har små børn og ditto indtægter, kan ikke tillade sig at tage på studieophold. Krig og politiske forhold stiller sig også hindrende i vejen. I stedet fuskes der på egen hånd. Om natten drømmer jeg om enetimer hos Medau.

Verdenssituationen gjorde, at noget gik skævt indenfor gymnastikkens udvikling. Den ydre effekt i Medaugymnastikken blev efterlignet. "Knævipninger« blev et begreb. (I mandsgymnastikken er de der mange steder endnu). Men det bærende i systemet - selve totaliteten - kom ikke med. Der blev foretaget et mekanisk og meningsforladt vip i knæene, så overkroppen blev flyttet ned og op med fixeret hvirvels øjle i stedet for den gennemløbende bevægelse, der med hoften som det styrende er fordelt på samtlige led. Karikaturen var grotesk, og resultatet blev en forsimpling af den nordiske gymnastik.

Krigen fik til følge, at Medaugymnastikken aldrig blev overført til Danmark i sin rene form. Der var ikke mulighed for studier ved kilden. I stedet kom der senere andre, f.eks. estlænderen Ernst Idla og finnen Hilma Jalkanen (der begge byggede på det tyske grundlag), som fortrængte mindet om Medau, uden at deres arbejde var nær på højde med hans.

Tilbage til slutningen af trediverne. Med sammenbidte tænder gik jeg igang med mit musikstudium. Til hver eneste $\emptyset$ velse skuller der »komponeres« musik, som nøje fulgte bevægelsen. Et »lydfotografi« som skulle indøves, så jeg kunne spille sikkert, mens jeg underviste. Det kunne jeg forsøge mig med i hveranden undervisningstime, når pianisten alligevel ikke var der.

Dette arbejde gik der sytten år med.

Drømmen om engang at få enetimer hos Medau blev knust af krigen.

\section{Fallit}

Min arbejdsbyrde var for stor i de år - med undervisning, stor familie og studier, men min opdragelse tvang mig til at blive ved. Når man har lært, at man skal blive på sin post, til man styrter, må den logiske følge blive at man styrter. Bagefter er det let nok at se, at det enorme arbejdspres skulle få mig i gulvet. Det blev bekræftet, at en energisk leder med et dårligt system er en farlig konstellation.

Usikkerheden om gymnastikkens værdi vokser. Femten år er der gået med forskellige systemer blandet sammen, og som sagt er der elever, der melder fra. Der optræder dårlige rygge og smertende skuldre, og lægerne begynder at antyde, at den gymnastik, der praktiseres, er skadelig.

Ømhed skulle vel ikke være tegn på akut overanstrengelse? Min dosis er ti gange så stor som elevernes. Træthed - $\emptyset$ mhed - smerter - det accelererer. Fortabt giver jeg først, da stemmen svigter totalt. 
$\mathrm{Nu}$ står valget imellem at holde helt op at undervise - eller at begynde forfra med modsat fortegn.

Den anspændte gymnastiklærer med den overanstrengte stemme måtte gøre status og revidere sin opdragelse, som bl.a. gik ud på, at man ikke klagede, når noget gjorde ondt. Man hærdede sig og holdt ud, trodsede besværligheder etc. etc. Mit havari medførte en konstatering af, at dette var livsfjendtlige synspunkter - dårlig økonomi, og at smerter netop er naturens hensigtsmæssige varsel om, at nu skal man enten hvile eller skifte arbejdsmetode.

Så melder ganske naturligt det samvittighedsspørgsmål sig: Hvad er det egentlig, du vil dine elever? Hvad vil du basere din undervisning på? Det er klart erkendt, at den gymnastik, jeg hidtil har praktiseret, er uegnet. Den er ufysiologisk og indøver fejlfunktioner. Målsætningen: dygtige »gymnaster « i stedet for harmoniske mennesker er forkert.

Det er ikke elevernes behov, der bliver tilgodeset - snarere lærerens. Altså forfra.

\section{Søgen}

Alt mit øvelsesstof må kasseres, og jeg har ikke noget andet at sætte i stedet endnu. Først skal der gøres erfaringer.

Det vigtigste i første omgang er afslapning og afspænding (afslapning = totalt ophør af spænding. Afspænding = ophør af overflødig spænding), for jeg kører med bremsen trukket - presser på og holder igen samtidig. Edmund Jacobsen og J. H. Schultz's bøger sætter mig igang. Total afslapning har aldrig været et problem for mig - men hvordan underviser man i det? Afspænding derimod har jeg i høj grad selv brug for at lære først.

Mens jeg koncentrerer mig om det, går det op for mig: Her er nøglen. Det er ved at arbejde med spænding/afspænding, man får kropsfølelse - gør bevidste kropserfaringer og dermed kan lære at koordinere! Det er basis for bevægelseslære.

En vej tegner sig.

Min talelidelse (fonasteni) nødvendiggjorde undervisning hos talepædagog, og der gjorde jeg flere erfaringer. Vagn Rehling formidlede på forbilledlig vis en forståelse af stemmeapparatet - dets opbygning og funktion samt forskellige former for fejlfunktioner med deres årsag og virkning. Undervisningen førte dels til det $\emptyset$ nskede resultat, og dels gav den mulighed for at drage paralleller til den samlede bevægelsesopdragelse, som så førte til denne tese: de grundregler, der gælder for det enkelte organ, må også galde for den samlede organisme.

Reglerne er: det skadede må først have den fornødne ro og hvile; derefter listes igang på lettest mulig måde i en lovmæssig udvikling - langs med en teoretisk forståelse af hvad der sker. Hvorfor og hvordan? Disse spørgsmål skal altid kunne besvares med logiske begrundelser. Det vil sige, at der foregår en bevidst tilegnelse af udviklingen: man oplever noget - føler det på sin krop - og får samtidig en holdbar teoretisk forklaring.

Det er det, jeg har savnet hele mit liv i gymnastikken. 
Taleundervisningens principper må kunne overføres til hele organismen. Her er $\emptyset$ velsesstof!

Mange gode hændelser hjælper mig på vej i disse år. 1952 får jeg Elli Björkstens legat og kan få sytten års inderligste ønske opfyldt: enetimer hos Medau. En årrække tog jeg til Tyskland for at lære, og det førte meget mere med sig end klaverspillet: Synet af den måde Medau brugte sin krop på for at få anslaget sådan, at klangen blev adækvat med den bevægelse, han ønskede at illustrere, og de informationer, han samtidig gav ud fra sin enorme viden om musik og totalbevægelse, faldt nøje i tråd med Rehlings pædagogik. Noget om organisk helhed og funktion i stedet for » $\emptyset$ velser« taget ud af sammenhæng.

Den tredje hjælp til at lægge arbejdet i salen helt om kom fra den norske neurolog Henrik Seyffarth. Han kritiserede $\mathrm{i}$ hårde vendinger den almindeligt anvendte gymnastik. Han skriver:

»Vi må huske at tross alle fine gymnastikteorier blir det endelige mål å gjenoprette og vedlikeholde de enkle funksjoner vi hadde som barn, men som vår sivilisasjon etter hvert tar fra oss. Her savner jeg målbevissthed hos den nåværende fysiske opdragelse. Det vrimler av forskjellige øvelser, men mange av dem synes å mangle noen bestemt hensikt. Det kan være bra med allsidig oppøving, men jeg vil be dere - lag først et program som lærer elevene muskelfølelse, avslapning, ånding - stå, sitte og gå«.

Det var karakteristisk, at de tre der gav mig impulserne: talepædagogen, musikeren med bevægelse som speciale og neurologen med de belastningsskadede patienter, alle tre arbejdede med kropsbevidsthed som grundlag. Og de begyndte alle tre ved et nulpunkt.

Muskelfølelse og kropsbevidsthed bliver nye ord i en søgende tid. Forum for nye strømninger var bl.a. den tværfaglige nordiske forening til forebyggelse af belastningssygdomme: »Helse og arbete«. Den blev stiftet i 1954, og dens tidsskrift behandlede emnet »det hele menneske« - både påvirkninger og modstandsevne - såvel af ydre som af indre art. Foreningen afholdt kongresser, og det var en kolossal hjælp til en ny arbejdsform at kunne hente viden fra andre faggrupper, ligesom det gav mig sikkerhed på min vej at blive bakket op fra medicinsk side. Foreningen var banebrydende, og alt, hvad der idag er en selvfølge om arbejdsteknik og bevægelsesfunktion, har haft sit udspring i originale artikler i tidsskriftet: »Helse og arbete«. For mandsgymnastikken i Danmark har især Jørgen Kellers arbejde haft stor betydning.

Hvordan går det så med kvindegymnastikken i de samme år?

Else Hamburger kom med et system, hvis bærende ide var, at man skulle søge balance med formindsket underst $\varnothing t$ telsesflade. Teorien blev sløret af, at hver $\emptyset$ velse skulle indledes med en kunstig fixering af hoftepartiet, der medførte kipning af bækkenet.

En af hendes dygtige elever: Liss Burmester populariserede systemet og gav det et jazzpræg - i tidens stil kunne man sige - men uden teoretisk begrundelse. 
Samtidig var afslapning blevet den store mode, og ved mange opvisninger i midten af århundredet kunne man se uskøn og umotiveret afslapning demonstrativt praktiseret: pludselig fald af armene fra høje stillinger med hårde rusk i skulderleddet til følge, uhæmmet fald af overkroppen forover - store fejesving med løst dinglende hoved - etc.

Det viste en misopfattelse af afslapningens anvendelse og var dermed et karrikaturbillede. Skolegymnastikken tog klart afstand fra »afslapningsraseriet«, og desværre kom afspænding ikke ind som fag på Danmarks Højskole for Legemsøvelser.

Der vil blive ved at komme nye moderetninger og nye teorier og stilarter - sommetider noget gammelt med nyt navn - men jeg følger det ikke mere med ops $\emptyset$ gende interesse. I stedet koncentrerer jeg mig om min egen vej, som nu ligger lysende klar.

\section{Sen erkendelse}

I uddannelsesøjemed er der ikke brug for mode og for systemer. Der er brug for en tidløs basis. En fysisk opdragelse, der bygger på viden og en holdbar teori - begyndende ved et nulpunkt.

Et sådant nulpunkt er læren om afspænding. Det er simpelthen forudsætningen for at kunne komme videre, da den er grundlag for kropsfølelse og dermed koordinering. Det var præcis, hvad jeg havde hårdt brug for i 1932 under min uddannelse.

Hvad er en holdbar teori? Hvad er sandt og tidløst?




Det er de konkrete og uforanderlige forhold, der er de givne menneskelige betingelser - som f.eks. de anatomiske: indbyrdes forhold mellem knoglerne - ledudformningen - muskelsynergierne. De fysiologiske: den nervøse regulering - medfødte reflekser og bevægelsesmønstre.

Endvidere lovene fra den mekaniske fysik som kan anvendes på mennesket i spændingsbalance: tyngdelov, inertiens lov, loven om aktion og reaktion, krydsningsloven og økonomiloven. Disse love kan bruges som kriterier i bevægelsesanalyser. Endelig er der den medfødte programmerede motoriske udvikling, som foregår trinvis med stadigt stigende krav til balancen. Til slut kunne medtages reglerne for arbejdsteknik, hvor mennesket fungerer mekanisk med en ydre modstand - hvor kropsstammen fixeres, og armene evt. bruges som kraner og benene som transportmiddel, og hvor man kan regne med kropstyngde og vægtstangsarme.

Arbejdet med alle disse ting optog mig dengang i halvtredserne så stærkt, at jeg følte mig kaldet til at skrive en gymnastikteori. Da jeg havde skrevet indholdsfortegnelsen, opgav jeg - og søgte råd hos professor Emanuel Hansen som klogt sagde: »Gymnastikteori - det er en altfor stor opgave«. Og så gav han mig det råd: »Vælg et lille emne og skrive Dem ud om det - så er det til side. Så kan De senere skrive om noget andet. Begynd f.eks. nedefra - skriv om fødderne«. Dybt taknemlig for det gode råd gik jeg hjem og begyndte. Det er tredive år siden, og teorien foreligger nu spredt i artikler og bøger.

\section{Lyden}

Med lyden er det gået sådan, at klaveret er blevet fjernet fra salen og i stedet er rytmeinstrumenter og båndoptager flyttet ind. Båndoptageren er et mekanisk led mellem lærer og elev. Indrømmet - det kan give et festligt tillæg til undervisningen, men det kan også binde læreren - som intet kan ændre spontant. Og det kan også være et intetsigende lydtapet, som læreren ovenikøbet skal anstrenge sig for at overdøve.

Jeg måler musikken med Medaus alen, men jeg indser nu det formålsløse i at fortsætte med at uddanne lærere efter hans fremgangsmåde. Kravene er urimeligt store både med hensyn til flid og begavelse, og klaveret er borte. Slut.

Men der er andre veje.

Fra kommando og tilsigelse over levende musik og båndoptager kan man nu vende det helt om og lade elevernes egne stemmer være en slags bevægelsesmusik. På Medauskolen skulle eleverne i musiktimerne først vise bevægelsen, mens de lydmæssigt udtrykte impuls og forløb, og så skulle de - stadig med stemmen i brug - med hænderne på klaveret prøve at gengive lydbilledet der.

Det var jo faktisk en omvej. Man kunne helt spare klaveret og nøjes med stemmen. Vel at mærke ikke kun lærerens, men elevernes egne. Det siges, at en af de største hæmninger vi har, findes på det lydmæssige område, så det ville være en god ide at gøre meget ud af stemmebrug - både tale og sang - i læreruddannelsen. Stemmen er jo lærerens vigtigste værktøj. Det er først muligt af få eleverne til at synge, når ens egne hæmninger er borte.

Den menneskelige stemme i alle afskygninger er en slags bevægelsesmusik (lyt til børnene der leger) - primitive lyde til primitive bevægelser (suk, støn, råb). Ikke kun- 
stige og mærkelige lyde, men spontan lydgivning samhørende med bevægelsen - kald det for min skyld gerne integreret respiration. Kultiverede lyde til kultiverede bevægelser - nynnen, sang, evt. flerstemmig sang og kanons etc. Der er ny vej frem, og det kan blive kunst. Der er arbejde nok til kommende generationer.

\section{Slut}

Nu slutter min historie. Jeg beklager meget ikke at have kendt Bess Mensendieck og Astrid Gøssel. Det er en stor fejl. Nutiden skal her ikke skrives om - det bliver jeres egen historie. Det er sikkert ikke lettere at være ung idag, end det var for tres år siden, for hvad er der ikke af valgmuligheder. Spektret er vidt.

Men fremtiden?

Hvis du kan glemme dig selv og din dygtighed og udelukkende tænker på hvad dit medmenneske i salen har brug for - så åbner der sig vej frem.

\section{Helle Gotveds skriftlige arbejder gennem årene}

\section{Artikler:}

Musik til afspaendingsgymnastik, Tidsskrift f.1. nr. 5, 1950

Status i gymnastiksalen, Tidsskrift f.1. nr. 4, 1955

Retningslinjer for kvindegymnastik, Tidsskrift f.1. nr. 5, 1955

Almindelig gang, Tidsskrift f.1. nr. 5, 1956

Nutidsgymnastik, Ungdom og Idræt, nr. 23, 1957

Arme bøj og arme strak, Politikens kronik, nr. 10/3, 1958

Bevagelsesfunktion og stemmebrug, Helse og arbete nr. 4, 1962

Respiration og fysisk genopdragelse, Helse og arbete nr. 3, 1967

Rygproblemer, Tidsskrift f.l. nr. 1, 1971

Totalbevagelse - fjedren og svingen, Tidsskrift f.1. nr. 3, 1972

Landens problemer, Helse og arbete, nr. 2, 1974

Fysisk opdragelse, Tidsskrift f. fysioterapeuter nr. 6, 1974

Kropsbevidsthed som grundlag for bevagelsespadagogik, Tidsskrift f.1. nr. 2, 1975

Forbedret respiration og cirkulation ved lydmetode, Helse og arbete, nr. 3, 1976

Lyd og bevaegelse, stemme og krop, Tidsskrift f.1. nr. 2, 1979

\section{Bøger:}

Ha det bedre - om afspaending og mindrevardskomplekser, Navers forlag, 1954

Stcerke fødder - smukke ben, Navers forlag, 1959

Ha det godt $i$ arbejde og hvile, Navers forlag, 1961

Musik og bevagelse, Navers forlag, 1962

Ha det bedre med fødderne, Haases forlag, 1972

Ha det bedre. Kropserfaring, Haases forlag, 1977

Bakkenbundens optraning, Munksgård forlag, 1979

Muskler og orgasme, Munksgård forlag, 1980

Skulderproblemer og armenes bevagelsesmønstre, Forlaget Bavnebanke, 1981

Ha det bedre fra morgenstunden, Fællesekspeditionen, 1981.

Helle Gotved, gymnastikpadagog 